\title{
Sample Treatment Procedures for the Determination of Mineral Constituents in Honey by Inductively Coupled Plasma Optical Emission Spectrometry
}

\author{
Teresa M. F. F. Mendes, ${ }^{\#}$ S Nivaldo Baccan and Solange Cadore* \\ Instituto de Química, Universidade Estadual de Campinas, CP 6154, 13084-971 Campinas-SP, Brazil
}

\begin{abstract}
Foram desenvolvidos métodos para a quantificação de constituintes inorgânicos em mel, usando-se digestão assistida por microondas e banho de ultra-som e determinação por espectrometria de emissão óptica em plasma, com acoplamento indutivo (ICP OES). No estudo foram considerados aspectos como a complexidade da matriz, otimização instrumental e essencialidade/toxicidade das espécies $\mathrm{K}, \mathrm{Ca}, \mathrm{Mg}, \mathrm{Na}, \mathrm{Fe}, \mathrm{Mn}, \mathrm{Zn}, \mathrm{Cu}, \mathrm{Co}, \mathrm{Ni}, \mathrm{Pb}$ e $\mathrm{Cd}$ e foram avaliados parâmetros como potência do plasma, vazão de nebulização, configuração da tocha e uso de ítrio como padrão interno. Foram obtidas recuperações entre 93 e 107\% (digestão assistida por microondas) e entre 90 e $110 \%$ (banho de ultra-som) com desvios-padrão relativos menores do que $10 \%$. Amostras de mel brasileiro, procedentes de diferentes Estados, foram analisadas para obtenção de informações sobre o seu conteúdo mineral. Os resultados obtidos foram comparados com aqueles obtidos em mel de diferentes origens.
\end{abstract}

Preparative methods for quantification of inorganic constituents in honey by Inductively Coupled Plasma Optical Emission Spectrometry (ICP OES) using microwave assisted digestion and ultrasonication procedures were developed. Analytical aspects such as matrix complexity, instrumental optimization and the essentiality/toxicity of the species $\mathrm{K}, \mathrm{Ca}$, $\mathrm{Mg}, \mathrm{Na}, \mathrm{Fe}, \mathrm{Mn}, \mathrm{Zn}, \mathrm{Cu}, \mathrm{Co}, \mathrm{Ni}, \mathrm{Pb}, \mathrm{Cd}$ were considered. Parameters such as plasma power, nebulizer flow rate, torch configuration and the convenience of the use of yttrium as internal standard were evaluated. Recoveries between 93 and 107\% (microwave digestion) and between 90 to $110 \%$ (ultrasonication procedure) and relative standard deviations lower than $10 \%$ were obtained. Samples of Brazilian honeys, from different parts of the country, were analysed and the results obtained provide relevant information about their mineral content.

Keywords: inorganic constituents, honey, ultrasonication, microwave digestion, ICP OES

\section{Introduction}

Honey can not be considered a complete food by human nutritional standards, but it does offer potential as a dietary supplement, being recommended for infants, senior citizens and invalids as it is an easily digestible foodstuff that may be ingested directly or used as a sweetener in a variety of products. It is a liquid or semi liquid product made up of about $80 \%$ $\mathrm{m} / \mathrm{m}$ solids, containing a mixture of carbohydrates such as fructose, glucose, maltose, and sucrose, traces of pollen and water, as well as enzymes. The concentration of mineral substances in honey has been calculated to be $0.17 \% \mathrm{~m} / \mathrm{m}$ but this may vary over a wide range. ${ }^{1,2}$

* e-mail: cadore@iqm.unicamp.br

\# Present Address: Departamento de Química, Universidade Federal de Roraima, Rio Branco, RR, Brasil.
Additionally, bee honey shows therapeutic features, like antioxidant properties, and these characteristics have attracted more and more consumers, increasing its commercialisation around the world ${ }^{3,4}$ and, consequently, research concerning the characterization of honeys as well as the determination of their mineral content. $^{5-8}$

Such studies assure identification of authenticity of honey and thus protect consumers from adulterated products. Relevant analytical information is provided by the presence of different amounts of inorganic species in honeys. This observation arises from the fact that different levels of concentrations of inorganic species present in honey can establish its geographic origin and, considering that these levels are strictly associated with the environment ${ }^{9-12}$ (in fact, honey, as a product of bees, may reflects pollutants present in an 
environment) they give evidences for the impact of environmental pollution within an area of around $7 \mathrm{~km}^{2}$.

The determination of inorganic constituents of honey by Inductively Coupled Plasma Optical Emission Spectrometry (ICP OES) is advantageous considering its multielementar characteristics that allow rapid analysis, with good precision and accuracy. However, honey is a complex matrix rich in organic matter and different procedures for sample preparation are proposed in the literature. ${ }^{10,12-14}$ Terrab et al. ${ }^{12}$ determined 24 minerals after calcination and sugar without prior digestion or ashing in samples of Spanish honey. Seven different sample preparation methods, including ashing with different reagents, digestion in a PTFE bomb and in a microwave oven were reported by Fodor and Molnar, ${ }^{13}$ for the determination of metal ions concentrations in honey by ICP OES.

Caroli and coworkers ${ }^{10,14}$ described an extensive study on the attempt to produce a sample of honey as a typical certified reference material (CRM) containing inorganic species, using inductively coupled plasma optical emission spectrometry (ICP OES) for the determination of $\mathrm{Cu}, \mathrm{Fe}$, Mn and Zn.

Brazil produces honey but there is a lack of information concerning the maximum tolerable levels of possible contaminants. Similarly there is little information about the content of inorganic species in Brazilian honeys. Usually the organic components or some physico-chemical properties are investigated in order to characterize the honeys. ${ }^{15,16}$

In this paper we evaluate sample preparation procedures based on the use of ultrasonication and microwave assisted digestion of honey prior to simultaneous determination of inorganic constituents in honey by ICP OES. Analytical features such as matrix complexity, instrumental optimisation, essential and/or toxic elements (macro-constituents as $\mathrm{Ca}, \mathrm{K}, \mathrm{Mg}$ and $\mathrm{Na}$, as well as the micro-constituents $\mathrm{Cd}$, $\mathrm{Co}, \mathrm{Cu}, \mathrm{Fe}, \mathrm{Mn}, \mathrm{Ni}, \mathrm{Pb}$ and $\mathrm{Zn}$ ) were considered. For optimisation of the instrumental conditions analytical measurements of the signal to noise ratio and signal to background ratio, varying radio-frequency power (RF), rate of nebulization, torch configuration and wavelengths were evaluated. Samples from different parts of Brazil as well as samples from different countries were analysed.

\section{Experimental}

\section{Samples}

Four trade mark Brazilian samples from the States of São Paulo (SP) and Minas Gerais (MG) were used for optimisation of the methods. Sixty-nine samples of Brazilian honey were purchased in markets from different regions of the country. Twelve other samples were purchased in different countries.

\section{Reagents and instrumentation}

All reagents used in the experiments were of analytical grade. Deionised water $(18.2 \mathrm{M} \Omega \mathrm{cm})$ obtained from a Milli-Q water system (Bedford, MA, USA) was used throughout. Stock solutions of all evaluated species were prepared with concentrations of $1000 \mathrm{mg} \mathrm{L}^{-1}$ in $2 \% \mathrm{v} / \mathrm{v} \mathrm{HNO}_{3}$, except for $\mathrm{K}$, which was directly diluted in the multielementar standard solution. Analytical calibration curves were prepared with four points after the dilution of the standard solutions containing $1000 \mathrm{mg} \mathrm{L}^{-1} \mathrm{~K}, 200 \mathrm{mg} \mathrm{L}^{-1} \mathrm{Ca}, \mathrm{Mg}, \mathrm{Na}, 20$ mg L ${ }^{-1} \mathrm{Co}, \mathrm{Cu}, \mathrm{Fe}, \mathrm{Mn}, \mathrm{Ni}, \mathrm{Pb}, \mathrm{Zn}$, and $10 \mathrm{mg} \mathrm{L}^{-1} \mathrm{Cd}$. Yttrium, as an internal standard, was used at a concentration of $2 \mathrm{mg} \mathrm{L}^{-1}$.

The measurements for simultaneous determination of the inorganic species were carried on with a Perkin-Elmer ICP OES instrument, model Optima 3000DV (Norwalk, CT, USA), equipped with a cross-flow nebulizer and allowing choice of the torch configuration between the radial or the axial mode in an integrated unit. ${ }^{17}$ Good calibration curves, linear over a wide range of analyte concentrations, multielemental response and adequate detectability were obtained.

\section{Sample preparation}

Dissolution using ultrasonication. $20.0 \mathrm{~g}$ of honey and $20 \mathrm{~g}$ of $\mathrm{H}_{2} \mathrm{O}$ were filtered and submitted to ultrasonication for 15 minutes. Afterwards, $1.0 \mathrm{~g}$ of the final solution was mixed with $0.5 \mathrm{~mL}$ of concentrated $\mathrm{HNO}_{3}, 0.5 \mathrm{~mL}$ of yttrium solution $\left(100.0 \mathrm{mg} \mathrm{L} \mathrm{g}^{-1}\right)$ was added as an internal standard and the volume completed to $25.0 \mathrm{~mL}$ with deionised water before analysis by ICP OES. This sample dilution is necessary to reduce solution viscosity.

Microwave assisted digestion. A mixture of $1.0 \mathrm{~g}$ of honey, $2.0 \mathrm{~mL}$ of concentrated $\mathrm{HNO}_{3}, 2.0 \mathrm{~mL}$ of $30 \%$ $\mathrm{v} / \mathrm{v} \mathrm{H}_{2} \mathrm{O}_{2}$, with $0.5 \mathrm{ml}$ of yttrium ( $\left.100.0 \mathrm{mg} \mathrm{L}^{-1}\right)$ as internal standard was submitted to a heating program in a closed microwave oven (Provecto Analitica - DGT 100; Campinas, Brazil) following the steps: $1 \mathrm{~min}$ at $320 \mathrm{~W}$, $2 \mathrm{~min}$ at $0 \mathrm{~W}, 5 \mathrm{~min}$ at $320 \mathrm{~W}, 5 \mathrm{~min}$ at $520 \mathrm{~W}$ and $5 \mathrm{~min}$ at $740 \mathrm{~W}$. The resulting solution was diluted with deionized water to $25.0 \mathrm{ml}$ in a volumetric flask before to be analyzed by ICP OES. 


\section{Instrument optimisation and determination of the elements}

In this study, instrument optimisation was established for the determination of inorganic constituents by means of the analytical measurements of signal to noise and signal to background ratios for the following parameters: radio-frequency power, nebulization flow rate, torch configuration and wavelengths.

The best nebulization flow rate was established by observing the analytical data for $0.4,0.6$ and $0.8 \mathrm{~L} \mathrm{~min}^{-1}$ under a RF power of $1.3 \mathrm{~kW}$. Afterwards the power was varied $(1.1,1.2$ and $1.3 \mathrm{~kW})$ in order to select the best one. The analytical signals were observed at different wavelengths and under different torch configuration, radial or axial, for the species of interest.

\section{Figures of merit}

The analytical performance was evaluated considering the relative standard deviation (RSD), limit of quantification (LOQ) and the background equivalent concentration (BEC). ${ }^{17-19}$

Due to the practical problems that this kind of sample presents concerning its transformation into a stable, homogeneous mass adequate for a certification project, there is no certified reference material of similar composition, although some efforts have been made. ${ }^{10}$ Thus, in this study, accuracy was checked using the recovery factor at two levels of fortification for four Brazilian samples from different commercial origins.

\section{Results and Discussion}

For the microwave procedure, the maximum amount of honey used was $1.0 \mathrm{~g}$ with a total volume not higher than $10 \mathrm{~mL}$. This amount of sample did not represent a problem for the digestion with the microwave oven used even if the recommendation of most manufacturers is not to use more than $0.5 \mathrm{~g}$.

Even for higher analytical intensities, obtained by using more concentrated solutions, in terms of quantity of honey present in solution, an expressive dispersion of the analytical signals was observed, particularly related to micro-elements, reflected directly in increased values of the RSD. This is probably due to the presence of higher concentrations of the residual nitric acid affecting plasma equilibrium, with the consequent variation of the analytical signal. This observation can be confirmed by changing the concentration of nitric acid while maintaining the same mass of honey sample. Thus, it was decided to dilute the final solution to $25.0 \mathrm{~mL}$, in which the residual acid concentration was volumetrically determined as being approximately $3 \% \mathrm{~m} / \mathrm{v}$, low enough to keep the RSD values in an acceptable interval.

For ultrasonication procedure, on the other hand, the concentration of the sample used is limited by instrument conditions, since the high organic matter content increases the solution viscosity and may clog the nebulizer and/or affect the sensitivity due to the formation of carbon compounds. Considering the heterogeneous characteristics of the sample in this study the concentration of sample used was $2 \% \mathrm{~m} / \mathrm{v}$, prepared from a more concentrated solution $(50 \% \mathrm{~m} / \mathrm{v})$. It is recommended to filter the solution in order to avoid impurities such as beeswax that might affect the measurements. This may be done using quantitative filter paper or a nylon sieve (100 mesh). It was observed experimentally that the procedure using the ultrasonication leads to better sample homogeneity that yields lower RSD values compared with the results obtained when the sample $(2 \%, \mathrm{~m} / \mathrm{v})$ was analysed by direct introduction in the ICP OES.

For both procedures evaluated the addition of $0.5 \mathrm{ml}$ $\mathrm{L}^{-1}$ of yttrium solution, as an internal standard, contributed to a relevant improvement of the analytical results, decreasing the intense effects caused by matrix interference and improving the precision of analytical signals.

In order to improve the performance of the analytical procedure it is important to optimise instrumental conditions, such as the coupled plasma power, plasma gas flow rate, observation height for radial torch mode, nebulization flow rate and the correct spectral line. ${ }^{20}$ The instrumental optimisation was carried out for both procedures.

The torch configuration was also investigated and it was observed experimentally that the axial mode shows the best LOQ and sensitivity compared to the radial mode, due to the larger observational region in the plasma. On the other hand, this configuration increases the levels of spectral interference and decreases the signal to background ratio. When the analyte concentration is high or when problems arise from the complexity of the matrix, use of the radial mode can be more convenient, mainly for elements showing low ionisation potential. ${ }^{10,21}$

Signal to noise ratios in the range of $10^{\circ}$ to $10^{3}$ and signal to background ratios in the range of $10^{\circ}$ to $10^{2}$ were observed when optimising the instrumental parameters for procedure using ultrasonication. For microwave assisted digestion it was observed that the signal to noise ratios were in the range of $10^{6}$ to $10^{8}$, while the ratio signal to background lies in the range of $10^{0}$ to $10^{3}$. 
a)

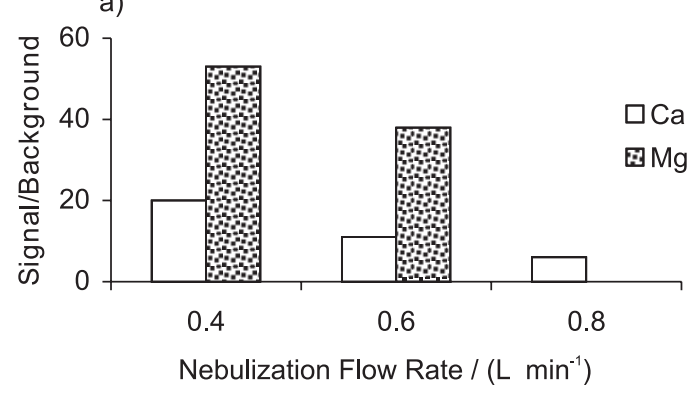

c)

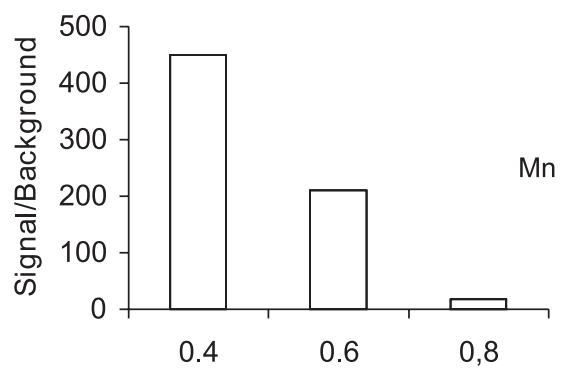

Nebulization Flow Rate / ( $\left.\mathrm{min}^{-1}\right)$

e)

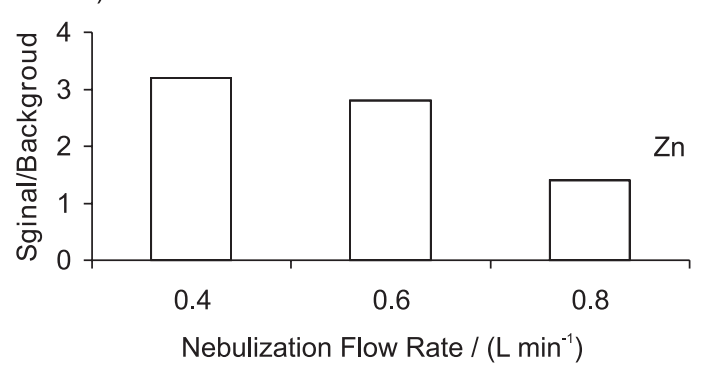

b)

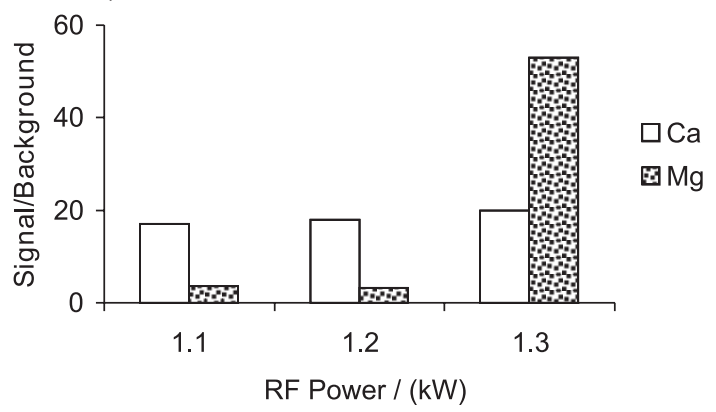

d)
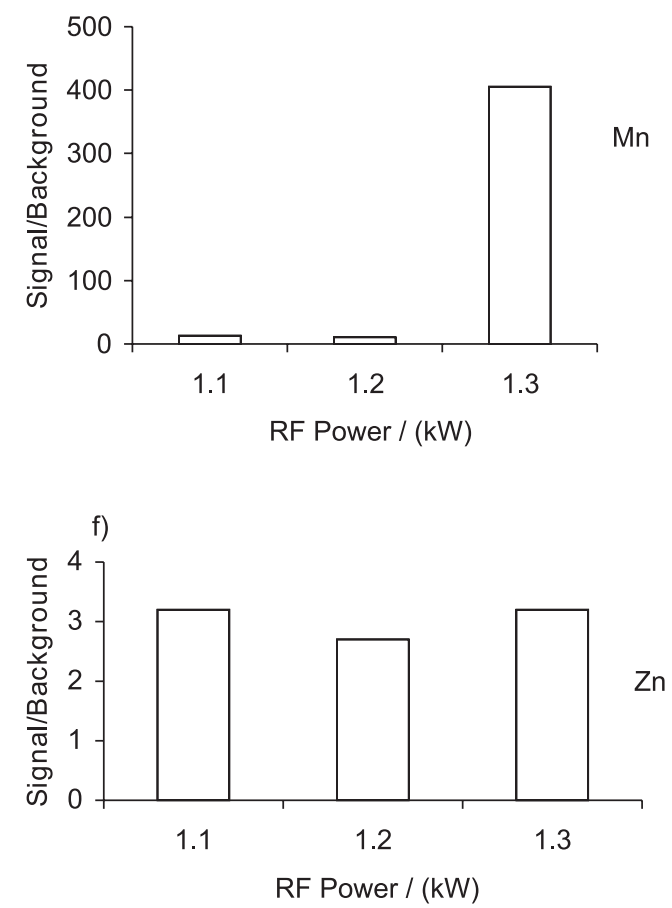

Figure 1. Signal to background ratio obtained with the instrument optimized for $\mathrm{Ca}$ ( $317.933 \mathrm{~nm}$, axial mode), Mg (279.079 nm, radial mode), Mn ( $257.610 \mathrm{~nm}$, axial mode) and $\mathrm{Zn}(213.856 \mathrm{~nm}$, axial mode): (a), (c) and (e) nebulization rate with $1.3 \mathrm{~kW}$ RF power; (b), (d) and (f) RF plasma power with a nebulization flow rate in $0.61 \mathrm{~min}^{-1}$. (Ultrasonication procedure).

As the best condition for a particular species is not necessarily the same for all it was decided to work under conditions optimised for some important elements, established as $\mathrm{Ca}, \mathrm{Mg}, \mathrm{Mn}$, and $\mathrm{Zn}$. Figure 1 shows the signal to background ratio obtained for a RF power of $1.3 \mathrm{~kW}$ and nebulization rates of $0.4,0.6$ and $0.8 \mathrm{~L}$ $\min ^{-1}$ (Figures 1a, 1c and 1e) and for a nebulization rate of $0.4 \mathrm{~L} \mathrm{~min}^{-1}$ with RF power of $1.1,1.2$ and $1.3 \mathrm{~kW}$ (Figures 1b, 1d and 1f) for these species, using the ultrasonication procedure. Analytical signals obtained under different RF power at a specific nebulization flow did not show relevant variations. However, under the same RF power, but with different nebulization flow rates, there are more significant variations, particularly for low concentration species. In this study the instrumental conditions were optimised at: nebulization flow rate of $0.4 \mathrm{~L} \mathrm{~min}{ }^{-1}$ and $\mathrm{RF}$ power of $1.3 \mathrm{~kW}$, for ultrasonication procedure and nebulization flow rate of $0.6 \mathrm{~L} \mathrm{~min}^{-1}$ and $\mathrm{RF}$ power of $1.3 \mathrm{~kW}$ for microwave digestion. .

Working with ICP OES it is difficult to have a spectral line completely free of spectral interference. However, there are some lines that show less interference than others. So, the choice of wavelength and torch mode, axial or radial, for the determination of a specific analyte is imperative in order to avoid overlap of spectral lines, particularly, as already mentioned, for low concentration species in solution. ${ }^{18,21}$

Table 1 shows the concentration recovery factors obtained for the analytes present in four different samples of commercial honey (A, B, C, D), using the ultrasonic procedure and Table 2 shows the results obtained by 
Table 1. Results obtained with four commercial honeys (A, B, C, D) using ultrasonication procedure

\begin{tabular}{|c|c|c|c|}
\hline \multirow{2}{*}{$\begin{array}{l}\text { Analyte line }(\lambda / \mathrm{nm}) \\
\text { Torch Configuration } \\
\text { LOQ }\left(\mathrm{mg} \mathrm{L}^{-1}\right) \\
\text { BEC }\left(\mathrm{mg} \mathrm{L}^{-1}\right) \\
\text { Concentration level added }\end{array}$} & \multirow{2}{*}{$\begin{array}{l}\text { Concentration } \\
\left(\mathrm{mg} \mathrm{kg}^{-1}\right)(\mathrm{RSD})\end{array}$} & \multicolumn{2}{|c|}{ Recovery \% (RSD) } \\
\hline & & $10.0 \mathrm{mg} \mathrm{L}^{-1}$ & $40.0 \mathrm{mg} \mathrm{L}^{-1}$ \\
\hline K I (766.491) & A: $1042.3(1.2)$ & A: $98.7(0.9)$ & A: $95.6(2.6)$ \\
\hline radial & B: $440.4(6.0)$ & B: $92.3(2.0)$ & B: $93.3(2.9)$ \\
\hline 2.1 & $\mathrm{C}:<\mathrm{LOQ}$ & C: 101.9 (4.6) & C: $98.6(5.8)$ \\
\hline 45.7 & D: $459.3(3.2)$ & D: $92.3(2.0)$ & D: $103.0(5.5)$ \\
\hline Concentration level added & & $2.0 \mathrm{mg} \mathrm{L}^{-1}$ & $8.0 \mathrm{mg} \mathrm{L}^{-1}$ \\
\hline Ca II (317.933) & A: $84.8(0.7)$ & A:106.7 (2.7) & A: $101.2(3.8)$ \\
\hline axial & B: $47.5(3.1)$ & B: $101.0(2.0)$ & B: $99.7(2.6)$ \\
\hline 0.04 & C: $41.7(3.2)$ & C: 105.7 (2.7) & C: 105.7 (6.7) \\
\hline 0.031 & D: $23.6(3.4)$ & D: $107.3(1.5)$ & D: $107.9(6.7)$ \\
\hline Mg I (279.079) & A: $57.7(2.9)$ & A: $106.6(9.1)$ & A: $100.1(1.5)$ \\
\hline radial & $\mathrm{B}:<\mathrm{LOQ}$ & B: $99.6(4.6)$ & B: $98.3(2.2)$ \\
\hline 0.95 & $\mathrm{C}:<\mathrm{LOQ}$ & C: 99.5 (2.6) & C: $93.2(0.9)$ \\
\hline 0.081 & D: $43.3(10.5)$ & D: $98.4(4.4)$ & D: $100.6(7.0)$ \\
\hline $\mathrm{Na}$ I (589.592) & A: $<$ LOQ & A: $94.0(5.6)$ & A: $92.2(6.8)$ \\
\hline radial & $\mathrm{B}:<\mathrm{LOQ}$ & B: $82.2(3.9)$ & B: 98.4 (15.7) \\
\hline 3.95 & $\mathrm{C}:<\mathrm{LOQ}$ & C: $81.7(0.3)$ & C: $88.4(6.7)$ \\
\hline 0.049 & $\mathrm{D}:<\mathrm{LOQ}$ & D: $88.6(1.5)$ & D: $93.6(4.7)$ \\
\hline Concentration level added & & $0.20 \mathrm{mg} \mathrm{L}^{-1}$ & $0.80 \mathrm{mg} \mathrm{L}^{-1}$ \\
\hline Mn II (257.610) & A: $7.8(2.1)$ & A: $109.5(1.7)$ & A: $106.2(0.7)$ \\
\hline axial & B: $2.0(6.5)$ & B: $101.7(2.8)$ & B: $101.4(2.3)$ \\
\hline 0.009 & $\mathrm{C}:<\mathrm{LOQ}$ & C: $107.6(4.2)$ & C: 106.1 (1.8) \\
\hline 0.68 & D: $1.1(3.1)$ & D: 106.9 (3.9) & D: $108.9(5.6)$ \\
\hline Zn I (213.856) & A: $2.9(7.7)$ & A: $117.7(3.3)$ & A: $111.5(1.2)$ \\
\hline axial & $\mathrm{B}:<\mathrm{LOQ}$ & B: $100.4(2.9)$ & B: $105.4(1.8)$ \\
\hline 0.11 & $\mathrm{C}:<\mathrm{LOQ}$ & C: $103.6(6.9)$ & C: 112.9 (1.7) \\
\hline 0.015 & D: $<$ LOQ & D: $109.9(10.5)$ & D: $109.6(7.2)$ \\
\hline $\mathrm{Cu}$ I (324.754) & $\mathrm{A}:<\mathrm{LOQ}$ & A: $104.5(0.1)$ & A: $104.3(0.9)$ \\
\hline axial & B: $<$ LOQ & B: $103.4(1.0)$ & B: $106.9(3.6)$ \\
\hline 0.13 & $\mathrm{C}:<\mathrm{LOQ}$ & C: 109.8 (3.9) & C: 109.9 (2.2) \\
\hline 0.28 & $\mathrm{D}:<\mathrm{LOQ}$ & D: $110.1(0.9)$ & D: $109.1(6.8)$ \\
\hline Co II (228.616) & $\mathrm{A}:<\mathrm{LOQ}$ & A: $106.0(0.1)$ & A: $102.6(1.8)$ \\
\hline axial & B: $<$ LOQ & B: 103.1 (1.8) & B: $104.5(2.0)$ \\
\hline 0.08 & $\mathrm{C}:<\mathrm{LOQ}$ & $\mathrm{C}: 106.6(6.2)$ & C: $108.8(0.8)$ \\
\hline 0.28 & $\mathrm{D}:<\mathrm{LOQ}$ & D: $105.0(0.9)$ & D: $110.1(7.2)$ \\
\hline Ni I (232.003) & $\mathrm{A}:<\mathrm{LOQ}$ & A: $100.3(5.2)$ & A: $100.8(0.3)$ \\
\hline axial & $\mathrm{B}:<\mathrm{LOQ}$ & B: $99.7(1.2)$ & B: $104.9(1.2)$ \\
\hline 0.624 & $\mathrm{C}:<\mathrm{LOQ}$ & C: $110.4(2.4)$ & C: 108.4 (1.5) \\
\hline 0.28 & $\mathrm{D}:<\mathrm{LOQ}$ & D: $102.8(6.1)$ & D: $109.7(4.4)$ \\
\hline Pb II (220.353) & $\mathrm{A}:<\mathrm{LOQ}$ & A: $95.4(3.1)$ & A: $100.0(2.1)$ \\
\hline axial & B: $<$ LOQ & B: 99.5 (4.3) & B: $103.3(2.5)$ \\
\hline 1.1 & $\mathrm{C}:<\mathrm{LOQ}$ & C: 109.1 (1.9) & C: 105.1 (1.4) \\
\hline 0.54 & $\mathrm{D}:<\mathrm{LOQ}$ & D: $98.6(2.6)$ & D: $109.1(5.4)$ \\
\hline Fe II (238.204) & $\mathrm{A}:<\mathrm{LOQ}$ & A: $102.4(0.9)$ & A: $107.3(1.7)$ \\
\hline axial & B: $<$ LOQ & B: $107.3(1.8)$ & B: $105.4(2.0)$ \\
\hline 0.08 & $\mathrm{C}:<\mathrm{LOQ}$ & C: $110.1(5.2)$ & C: $108.1(0.9)$ \\
\hline 0.08 & D: $<$ LOQ & D: $110.9(0.5)$ & D: $110.0(6.8)$ \\
\hline Concentration level added & & $0.10 \mathrm{mg} \mathrm{L}^{-1}$ & $0.40 \mathrm{mg} \mathrm{L}^{-1}$ \\
\hline Cd II (214.438) & $\mathrm{A}:<\mathrm{LOQ}$ & A: $99.9(0.8)$ & A: $100.9(3.47)$ \\
\hline axial & B: $<$ LOQ & B: $101.7(2.3)$ & B: $105.4(2.0)$ \\
\hline 0.04 & $\mathrm{C}:<\mathrm{LOQ}$ & C: 110.1 (4.6) & C: $110.1(1.0)$ \\
\hline 0.24 & $\mathrm{D}:<\mathrm{LOQ}$ & D: $106.6(1.1)$ & D: $103.5(3.2)$ \\
\hline
\end{tabular}


microwave assisted digestion, including the wavelength, torch configuration, LOQ, and BEC. The limits of quantification were calculated as suggested by Boss and Fredeen: $:{ }^{17} \mathrm{LOQ}=5 \times \mathrm{LOD}$, where LOD $=(3 \times \mathrm{RSD} \times$ $\mathrm{BEC}) / 100$. BEC corresponds to the background equivalent concentration, which was determined experimentally using the optimized conditions.

Most of the works available in the literature describe calcination or acid digestion in PTFE bombs using a pressure system or a microwave oven as sample treatment. The evaluation made in this work by using microwave assisted digestion and ultrasonication allowed adequate and simple procedures for the determination of inorganic ions in honey samples.

For both procedures it was observed that the recovery values for most of the species lie between 90 to $110 \%$. Due to the low concentration of many chemical species present in the different samples analysed, according to their particular origin, these recovery factor can be considered satisfactory, showing RSD lower than $10 \%$ for most of the species.

There is no significant difference, within a confidence level of $95 \%$, between the results obtained when samples were treated with the ultrasonication, compared with those reported for microwave oven treatment. In a general way microwave assisted digestion showed lower RSD values but higher blanks. Considering some advantages presented by ultrasonication compared with microwave procedure, such as the lower amount of sample, and the less time for sample treatment, it was used for the subsequent analysis.

The ultrasonication procedure was applied to the analysis of 69 samples of honey from the South, Southeast, North, Northeast and Centre-West Regions of Brazil and the results obtained for different inorganic constituents are shown in Table 3. Individual values were summed to a total that may represent, in an approximate way, the mineral content of the samples. According to Anklam $^{22}$ and Buldini et al..$^{23}$ the mineral content of the honey indicates its purity level and should not exceed $0.2 \% \mathrm{~m} / \mathrm{m}$. In this study it was observed that about $80 \%$ of the samples analysed are within this value. Besides this, $\mathrm{Cd}$ and $\mathrm{Pb}$ levels are below LOQ (0.04 and $1.0 \mathrm{mg}$ $\mathrm{L}^{-1}$, respectively), suggesting that Brazilian honeys are, in general, free of these contaminants. According to the Brazilian Agency for Health and Safety (ANVISA), the maximum value accepted for lead in sugar is $2.0 \mathrm{mg}$ $\mathrm{L}^{-1}$ while for cadmium there is no recommendation. ${ }^{24}$ The value of $1.0 \mathrm{mg} \mathrm{L}^{-1}$, suggested for foods, was arbitrarily adopted for this consideration.

According to the FDA (Food and Drug Administration) a food may be classified as a good nutritional source if it contains 10-19\% of the DRV (daily reference values) and as a rich source if it contains $20 \%$ or more of the DRV for a claimed nutrient. ${ }^{25}$ A comparison between the results obtained in this study and the DRV values for the ingestion of minerals, as recommended by WHO (World Health Organization), showed that approximately $80 \%$ of the honey analysed can be considered as a good or a rich source of Mn while the levels of the other species evaluated are below $10 \%$ of the DRV.

There are several parameters that influence the mineral content of honeys, such as temperature, humidity, soil and floral type, among others. Considering the dimension of Brazil, the number of samples analysed and the number of species determined in this work, it is not possible to make definitive conclusions about the mineral content of honey. A larger number of samples from all the different regions and a higher control of the aspects described above are recommended, however, the results obtained may give an important contribution, considering that little information on this is available in this country. Actually, as a consequence of this preliminary work we are developing more extensive studies related to this matrix.

Similarly, it is difficult to compare the results obtained for honeys from Brazil and other countries. Different authors use distinct methods of sample preparation and techniques of analysis but, in general, the results obtained for Brazilian honeys are in good agreement with those obtained and/or reported for honeys from other countries, as described in Table 4.

\section{Conclusions}

The use of ultrasonication or digestion assisted by microwave provides efficient procedures, simple treatment for homogenizing bee honey samples before determination of inorganic species, overcoming matrix effects and spectral interferences in an efficient way, showing accuracy and precision.

The concentration ranges of inorganic species in honey are large and this may be attributed to the dimension of the country that implies differences in climatic conditions.

In a general way, Brazilian honey did not show contamination by potentially toxic species and is a good source of manganese.

The results obtained for Brazilian honeys agree with those from other countries (obtained by the authors or described in the literature). Thus the present study contributes for information about the mineral content of a variety of honeys. 
Table 2. Results obtained with four commercial honeys (A, B, C, D) using microwave assisted digestion procedure

\begin{tabular}{lll}
\hline Analyte line $(\lambda / \mathrm{nm})$ & $\begin{array}{l}\text { Concentration } \\
\left(\mathrm{mg} \mathrm{kg}^{-1}\right)(\mathrm{RSD})\end{array}$ & Recovery \% (RSD) \\
Torch Configuration & & \\
LOQ $\left(\mathrm{mg} \mathrm{L}^{-1}\right)$ & & \\
BEC $\left(\mathrm{mg} \mathrm{L}^{-1}\right)$ & &
\end{tabular}

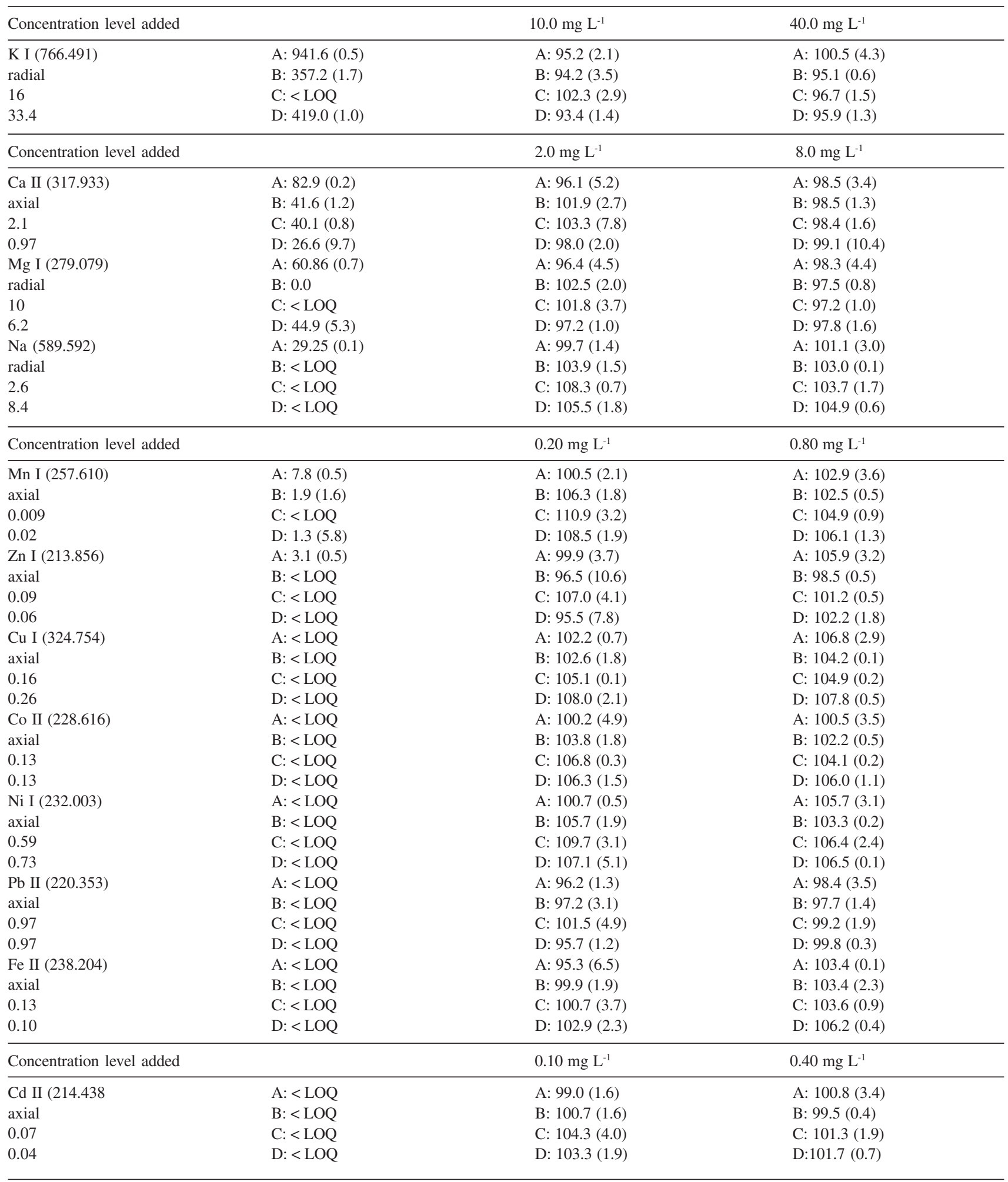


Table 3. Inorganic species in Brazilian honey samples ( $\mathrm{m} \mathrm{kg}^{-1}$ ) (ultrasonication procedure)

\begin{tabular}{|c|c|c|c|c|c|}
\hline $\begin{array}{l}\text { Brazilian Regions } \\
\text { Samples }\end{array}$ & $\begin{array}{c}\text { Centre West } \\
3\end{array}$ & $\begin{array}{c}\text { North } \\
2\end{array}$ & $\begin{array}{c}\text { Northeast } \\
16\end{array}$ & $\begin{array}{c}\text { South } \\
16\end{array}$ & $\begin{array}{c}\text { Southeast } \\
32\end{array}$ \\
\hline K & $672-3353$ & $900-1510$ & $358-1402$ & $344-2950$ & $167-2500$ \\
\hline $\mathrm{Ca}$ & $18-38$ & $15-30$ & $7-214$ & $17-201$ & $5-234$ \\
\hline $\mathrm{Mg}$ & $48-57$ & $38-53$ & $<\mathrm{LOQ}-245$ & $<$ LOQ -195 & $<\mathrm{LOQ}-373$ \\
\hline $\mathrm{Mn}$ & $0.9-2$ & $1-17$ & $<\mathrm{LOQ}-5$ & $0.8-11$ & $<\mathrm{LOQ}-24$ \\
\hline $\mathrm{Zn}$ & $<\mathrm{LOQ}$ & $<\mathrm{LOQ}-14$ & $<\mathrm{LOQ}-12$ & $<$ LOQ - 11 & $<\mathrm{LOQ}-7$ \\
\hline $\mathrm{Fe}$ & $0.7-3$ & $<\mathrm{LOQ}-2$ & $<\mathrm{LOQ}-4$ & $0.6-15$ & $<\mathrm{LOQ}-15$ \\
\hline$\Sigma$ Conc. & $740-3453$ & $954-1612$ & $365-1882$ & $363-3383$ & $172-2787$ \\
\hline
\end{tabular}

Table 4. Concentration of some inorganic species found in honeys from different origins ( $\left.\mathrm{mg} \mathrm{kg}^{-1}\right)$. The values correspond to a range or an average content of the considered species (ultrasonication procedure)

\begin{tabular}{|c|c|c|c|c|c|c|c|c|}
\hline Origin of honey & $\mathrm{K}$ & $\mathrm{Ca}$ & $\mathrm{Mg}$ & Mn & $\mathrm{Fe}$ & $\mathrm{Zn}$ & $\mathrm{Pb}$ & $\mathrm{Cd}$ \\
\hline Not specified ${ }^{7}$ & & & & $0.11-7.22$ & & & & $0.09-0.22$ \\
\hline Not specified ${ }^{10}$ & & & & $1.82-1.98$ & $0.91-0.94$ & $0.40-0.41$ & $0.13-0.14$ & \\
\hline Not specified ${ }^{10}$ & & & & & $0.20-0.22$ & 0.17 & 0.02 & \\
\hline Poland ${ }^{11}$ & & & & & & 7.76 & 0.05 & 0.02 \\
\hline Spain $^{12}$ & $175-1380$ & $68.5-261$ & $38-140$ & $0.37-6.17$ & $3.7-11.5$ & $0.75-2.48$ & $0.04-0.26$ & $0-0.01$ \\
\hline Hungary $^{13}$ & $1047-370$ & $25-185$ & & $0.6-5.8$ & $8-33$ & $3.3-84$ & 2.4 & 0.1 \\
\hline Brazil (this work) & $167-3353$ & $7-237$ & $<$ LOQ-195 & $<$ LOQ-24 & $<\mathrm{LOQ}-15$ & $<\mathrm{LOQ}-14$ & $<\mathrm{LOQ}$ & $<$ LOQ \\
\hline Argentina (this work) & 537 & 18 & 25 & 0.7 & 2.3 & $<\mathrm{LOQ}$ & $<\mathrm{LOQ}$ & \\
\hline Germany (this work) & $582-740$ & $19.0-24.7$ & $22-34$ & $0.8-1.5$ & $3.6-4.1$ & $10.6-53.3$ & $<$ LOQ-4.6 & \\
\hline Belgium (this work) & 961 & 23 & 29.2 & 1.1 & 3.6 & 9.6 & $<\mathrm{LOQ}$ & \\
\hline France (this work) & 327 & 6.6 & $<$ LOQ & 0.1 & $<\mathrm{LOQ}$ & 8.2 & $<\mathrm{LOQ}$ & \\
\hline Italy (this work) & $345-423$ & $13.3-23.7$ & $<$ LOQ & $0.3-0.4$ & $<$ LOQ -1.5 & $0.1-19.3$ & $<\mathrm{LOQ}$ & \\
\hline
\end{tabular}

LOQ values described in Table 1.

\section{Acknowledgments}

The authors gratefully acknowledge Dr. Carol H. Collins for assistance with English in this manuscript and Fundação de Amparo à Pesquisa do Estado de São Paulo (FAPESP) and Fundação Coordenação de Aperfeiçoamento de Pessoal de Ensino Superior (CAPES/PICDT) for financial support of this work.

\section{References}

1. Celechovská, O.; Vorlová, L.; Acta Vet. BRNO 2001, 70, 91.

2. Mendes, E.; Brojo-Proença, E.; Ferreira, I.M.P.L.V.O.; Ferreira, M.A.; Carbohydr. Polym. 1998, 37, 219.

3. Cutler, D.; Pestell, K.; Trends Pharmacol. Sci. 2001, 22, 449.

4. Costa, L.S.M.; Albuquerque, M.L.S.; Trugo, L.C. Quinteiro, L.M.C.; Barth, O.M.; Ribeiro, M.; De Maria, C.A.B.; Food Chem. 1999, 65, 347.

5. Packer, A.P.; Giné, M.F.; Spectrochim. Acta, Part B 2001, 56, 69.

6. Sanna, G.; Pilo, M.I.; Piu, P.C.; Tapparo, A.; Seeber, R.; Anal. Chim. Acta 2000, 415, 165.

7. Ioannidou, M.D.; Zachariadis, G.A.; Anthemidis, A.N.; Stratis, J.A.; Talanta 2005, 65, 92.
8. Felsner, M.L.; Cano, C.B.; Matos, J.R.; Almeida-Muradian, L.B.; Bruns, R.E.; J. Braz. Chem. Soc. 2004, 15, 797.

9. Leita, L.; Muhlbachova, G.; Cesco, S.; Barbattini, R.; Mondini, C.; Environ. Monit. Assess. 1996, 43,1.

10. Carolli, S.; Forte, G.; Alessandrelli, M.; Cresti, R.; Spagnoli, M.; D’Ilio, S.; Pauwels, J.; Kramer, G.N.; Microchem. J. 2000, 6, 227.

11. Przybylowski, P.; Wilczynska, A.; Food Chem. 2001, 74, 289.

12. Terrab, A.; Hernanz, D.; Heredia, F.J.; J. Agric. Food Chem. 2004, 52, 3441.

13. Fodor, P.; Molnar, E.; Mikrochim. Acta 1993, 112,113.

14. Caroli, S.; Forte, G.; Iamiceli, A.L.; Galoppi, B.; Talanta 1999, $50,327$.

15. Leite, J.M.C.; Trugo, L.C.; Costa, L.S.M.; Quinteiro, L.M.C.; Barth, O.M.; Dutra, V.M.L.; De Maria, C.A.B.; Food Chem. 2000, 70, 93.

16. Felsner, M.L.; Cano, C.B.; Bruns, R.E.; Watanabe, H.M.; Almeida-Muradian, L.B.; Matos, J.R.; J. Food Compos. Anal. 2004, 17, 737.

17. Boss, C. B.; Fredeen, K. J.; Concepts, Instrumentation and Techniques in Inductively Coupled Plasma Optical Emission Spectrometry, $2^{\text {nd }}$ ed, Perkin-Elmer Corp.: Norwalk, 1999.

18. De Sousa, R.A.; Baccan, N.; Cadore, S.; J. Braz. Chem. Soc. 2005, 16, 540 . 
19. Silva, J.C.J.; Baccan, N.; Nóbrega, J.A.; J. Braz. Chem. Soc. 2003, 14, 310 .

20. Skoog, D.A.; Holler, F.J.; Nieman, T. A.; Princípios de Análise Instrumental, $5^{\text {th }}$ ed., Bookman Companhia Editora: Porto Alegre, 2002.

21. Thomsen, V.; Roberts, G.; Burgess, K.; Spectroscopy 2000 , 15,33 .

22. Anklam, E.; Food Chem. 1998, 63, 549.
23. Buldini, P.L.; Cavalli, S.; Mevoli, A.; Sharma, L.; Food Chem. 2001, 73, 487.

24. http:// www.anvisa.gov.br, accessed in August 2005.

25. Altman, T. A.; FDA and USDA Nutrition Labelling Guide Decision Diagrams, Checklists and Regulations, Technomic Publishing Co.: Pennsylvania, 1998.

Received: June 4, 2005

Published on the web: January 13, 2006

FAPESP helped in meeting the publication costs of this article. 